\title{
Multi-Phase Flow Dynamics Visualization by Using a Fast X-ray CT Scanner
}

Masaki MISAWA, Naoki ICHIKAWA and Makoto AKAI

\begin{abstract}
Multi-dimensional interface structure in air-water two-phase flow was visualized by using a fast X-ray CT scanner, which is able to scan a cross section approximately 100 times faster than conventional systems. To simulate flow channels in heat exchangers, locations and pitches of 3 rods were varied in a vertical tube. Gas-phase distribution in the cross section was reconstructed for analysis of the void fraction and the interface area concentration. The same facility was then used to visualize the water jet interface while penetrating through a Fluorinart pool. Due to relatively large density difference between the two immiscible fluids(1.7), the deformed interface structure was successfully detected. For visualization of overall jet interface, the jet nozzle was lifted upward at a constant velocity while scanning the cross section. In both two-phase flow and water jet interface visualizations, quantitative measurements of the phase distribution and the interface area concentration were made from reconstructed cross section images.
\end{abstract}

Keywords: Visualization, Fast X-ray CT, Two-phase Flow, FCI, Interface Area

\section{1. 緒 論}

気体、液体、固体が混合して流れる混相流は、家庭内 のエアコンから原子カプラントや化学プラントに至る 様々な機器に見られる流動形態だが、分散相の分布によ って压力損失や伝熱効率が変化するため、混相流機器の 特性が大きく変化する。また、単相流に扔ける Re 数の ような無次元数で予測できるスケーリング則が確立され ていないため、提案されるモデルは圧力や流量などの塞 験条件に依存している場合が多い。混相流を特徵づける パラメー夕の中で、界面積濃度 (単位: $\mathrm{m}^{2} / \mathrm{m}^{3}$ 、単位体 積あたりの界面面積）は、相間の質量、運動量、エネル ギーの輸送に直接関係するので、高精度の実験式が要求 されている 1。しかし、界面面積は複雑に変化する気泡 などの形状を多次元的に求める必要があるので、变形の 著しい大気泡や、気泡の密度が高く可視光による計測が 妨げられる状況では、正確な計測が困難であった2)。高 速X線 C Tは、これらの問題を解決するため、透過率の 高いX線を使い、画像再構成によって流路断面内の分布 を二次元的に可視化する装置である。さらに、医療用と は異なり、気泡のような移動する变形体の界面を検出す る必要があるので、スキャン時間を通常の C T 装置の約 $1 / 100$ に短縮している点に特徴がある。本報告では、こ の装置を使って可視化した気液二相流の気泡分布計測と、 液体ジェットの界面構造計測の 2 つの例を紹介寸る。

\section{2. 高速 X線 C T の仕様と測定精度}

\section{1 高速 X線 C T の構成}

高速 X 線C Tの概要をFig.1 1示す。この装置では、 18 個の X 線源と 122 個のシンチレー夕検出器が測定部 のまわりに固定配置されており、X線の照射を電気的に 制御することで、機械的な回転動作と等価な動きを実現
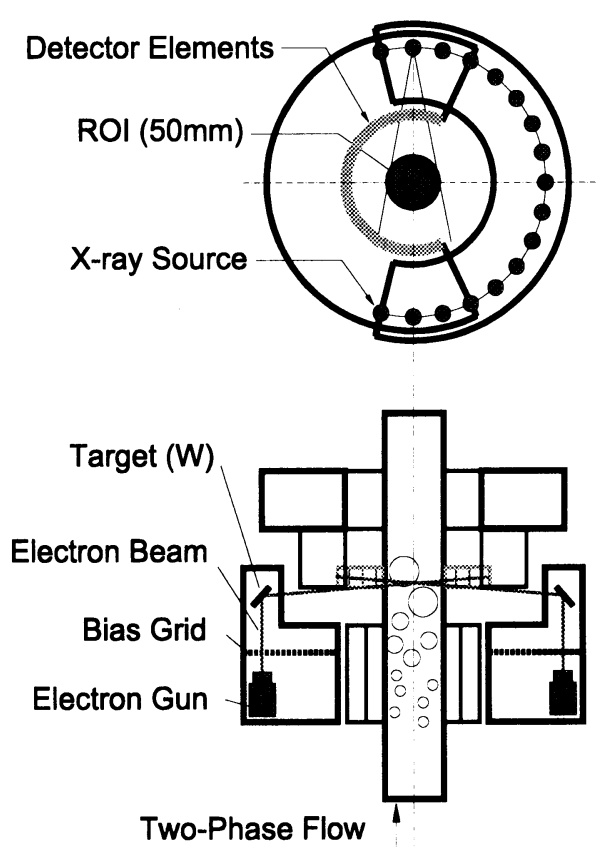

Fig. 1 Schematic Diagram of a Fast X-ray CT Scanner 
している。機械的な駆動部分がないので、スキャン速度 の高速化が可能になっている。撮影時は $100 \mathrm{kV} 、 5 \mathrm{~mA}$ の管電流で $100 \mu$ 秒の X 線照射を行い、一回のX 線ファ ンビームで照射される 32 個の検出素子で投影デー夕を 収集する。これを 18 方向から照射して得られたデー夕 セットを用いて、129x129 ピクセルのフォーマットで、 256 階調のグレースケール断層像として再構成される。 照射速度はX $\mathrm{X}$ 線源の切り替え速度と、デー夕の蓄積時間 によって制限される。デー夕の蓄積時間に対する制限は、 時間分解能を追求するうえで新たに課せられた制約条件 である。

\section{2 測定精度の評価}

本装置では、検出器ピッチおよびX線源ピッチから決 まる測定領域の空間分解能は約 $2.5 \mathrm{~mm}$ だが、移動速度 によって軸方向の分解能が影響を受けるため、直径 $5 \mathrm{~mm}$ の球形気泡でも移動速度が $1 \mathrm{~m} / \mathrm{s}$ を超えると再現性が低 下寸る。そこで、混相流の計測で重要となる断面積や表 面積の測定精度を評価するため、寸法が既知の円筒およ び球を重ねて連結したアクリル製モデルを作製し、これ らを一定速度で移動させて、高速 X 線 C T で断層撮影を 行った。適切なしきい值を設定して断層像を二值化し、 移動速度から断面間の距離を算出して、3 次元表示した ものを Fig. 2 に示す。移動速度が $1.0 \mathrm{~m} / \mathrm{s}$ を超えると、 形状の歪みが大きくなること、移動方向に対して断面形 状の変化が大きい球の方が変形の程度が大きいことがわ かる。C T計測から求められたモデルの体積と表面積を、 既知の值と比較した結果、寸法が小さいほど、また移動 速度が大きくなるほど、計測誤差が大きくなるが、寸法 が $10 \mathrm{~mm}$ 以上のモデルに対しては約 $20 \%$ の測定精度で 体皘や表面積が測定できることがわかった。実際の二相 流計測では、モデルで用いたような単純な形状ではない が、他に検証の方法もないため、このアクリルモデル計 測で得られた結果から実際の混相流の計測精度を推定し ている。
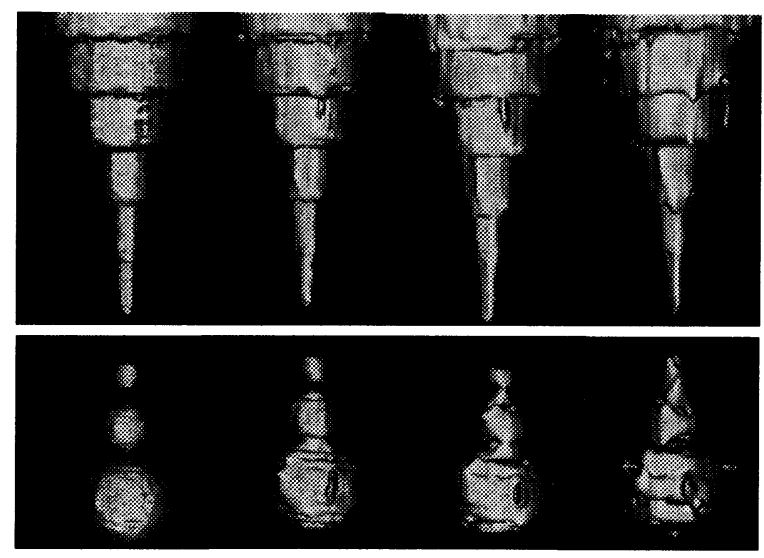

$\mathrm{V}=0.2 \mathrm{~m} / \mathrm{s}$

$0.6 \mathrm{~m} / \mathrm{s}$

$1.0 \mathrm{~m} / \mathrm{s}$

$1.6 \mathrm{~m} / \mathrm{s}$

Fig. 2 Reconstructed Acrylic Models

\section{3 . 気液二相流の界面計測}

\section{1 流体ループおよび流動条件}

垂直管内を流れる水一空気二相流のボイド率および界 面面積を計測するため、内径 $46 \mathrm{~mm}$ の垂直管を含む流 体ループを高速 X 線 C T装置内に設置し、気液流速をそ れぞれ変化させた条件のもとで、断層撮影を行った。ま た、熱交換器の管群を模擬するため、垂直管内に外径 $8 \mathrm{~mm}$ のロッドを 3 本配置して、気泡分布に対寸る影響 を調べた。ガス流量拉よび液流量は、それぞれ $0.19 \mathrm{~m} / \mathrm{s}$ および $0.61 \mathrm{~m} / \mathrm{s}$ の範囲で変化させた。この条件では、流 動様式は、気泡流からスラグ流までをカバーしている 測定位置は気液混合部から約 $0.93 \mathrm{~m}$ 下流で、 $\mathrm{L} / \mathrm{D}=22.6$ に相当する。液流量計、ガス流量計、压力計からの出力 はパソコンに取り込み、流動条件を解析した。

\section{2 流路断面内の気泡分布計測}

ロッドを中心部に配置した場合（CaseA）とロッドを 配置しない垂直流路内 (CaseD) の気液分布計測の一 例をFig. 3 に示す。この図では流量が比較的大きいとき、

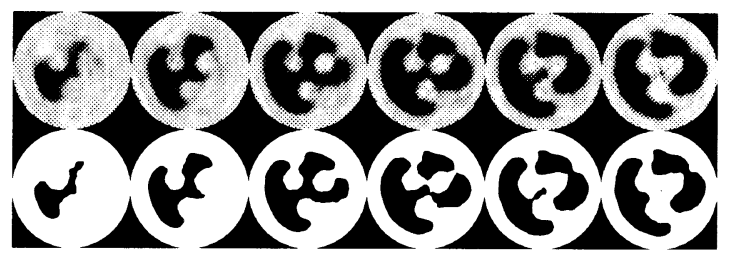

(a) Case A (3 rods in a $50 \mathrm{~mm}$ diameter tube)

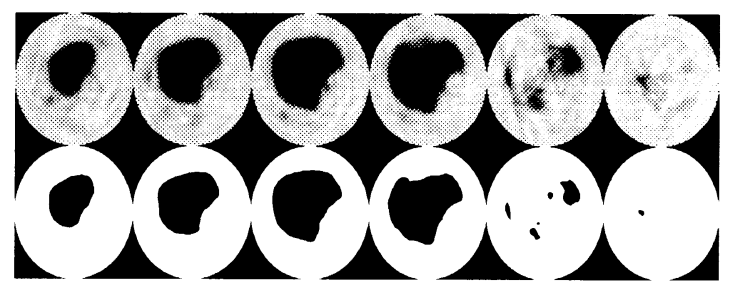

(b) Case $\mathrm{D}$ (No rods in a $50 \mathrm{~mm}$ diameter tube)

Fig. 3 Phase Distribution in a Cross Section

管内にスラグ気泡が形成され、高速 X 線 C T の測定断面 を通過している様子を表している。局所プローブを用い て断面内のある点のみを計測する従来の方法では、非均 質に断面内に分布する界面形状を捉えることはできなか ったが、高速 X 線C Tによって気泡断面を可視化するこ とにより、スラグ気泡の変形度を定量的に捉える事がで きる。また、ロッドが流路内にあるような複雑な流路形 状でも、同じ手法で計測できることは非破壊計測の利点 である。得られた断層像から、ボイド率や界面面積を求 めるには、しきい值を設定して二值化する必要がある (Fig.3)。画像処理に上って気泡部分 (図中、黑い部分) のピクセル数をカウントして断面平均ボイド率を算出す ると同時に、気泡部分の輪郭長さを求めて断面平均界面 積を算出した。これらの時間変化をブロットしたものが、 Fig. 4 である。流路断面形状の異なる二つの流路内の界 面面積濃度を比較するため、界面長さは流路の固体壁長 


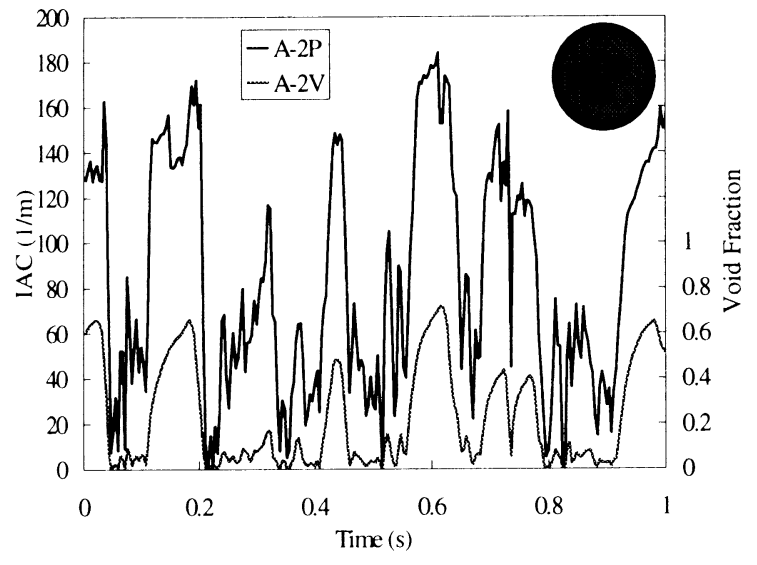

Fig. 4 Void Fraction and Interface Area Concentration Averaged in a Cross Section さで規格化した。図中の大きなピークはスラグ気泡の通 過に相当し、小さいピークは小気泡の通過に対応してい る。また、界面輸送は主としてスラグ気泡が担っている ため、界面面積とボイド率のピークはほぼ致している。

\section{3 スラグ気泡の变形係数}

高速 X 線 C Tによる断面計測の利点のひとつは、気泡 の全体像を捉え、その変形度を可視化できる点である。 界面の変形は実効的な界面面積を求める際に重要となる が、実験的な裏付けが不足していたため、適切なモデル 化はなされていなかった。ここでは、界面の変形度とし て、気泡断面積と等価な円の円周に対する輪郭長さの比 として定義している。ここで対象としているスラグ流で は、スラグ気泡とそれ以外の小気泡に対し、二つの代表 的なスケールがあるので、気泡流一スラグ流の遷移条件 となるボイド率 0.2 に相当する気泡径を基準として、ス ラグ気泡と小気泡それぞれについて平均的な変形係数を 求めた。断層像の画像処理から求めた変形係数を、体皘 流量に対してプロットした図がFig.5である。等価気泡 径が增加するにつれて液の乱れによる変形が顕著になる ため、スラグ気泡の変形係数 $\mathrm{C}_{\mathrm{c} t \mathrm{~S}}$ は増加するが、気泡 径が流路径に近づくと流路壁により变形が抑制される。

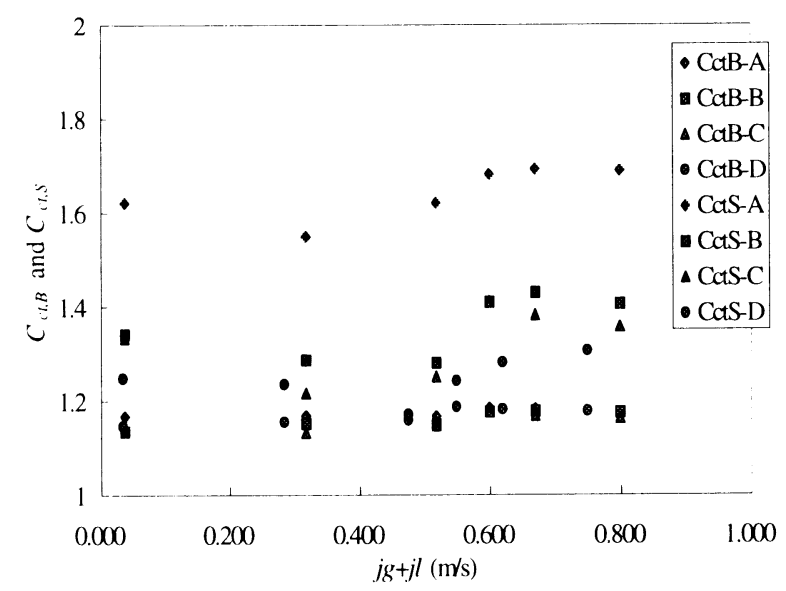

Fig. 5 Deformation Factor for Total Superficial Velocity, $j g+j l$
また、ロッドの配置によって変形係数の分布が異なるこ とがわかる。二流体モデルの代表的な計算コードである RELAP-MOD3 でも、スラグ流の変形係数として 2.0 を提案しているが 3、本実験でもこれに近い值が得られ ている。

\section{4. 液体ジェットの界面構造計測}

原子力施設に扔ける安全解析の一環として、シビアア クシデントに打ける熱流動解析技術の高度化があげられ る 1)。溶融物の落下と冷却材の相互作用 (FCI、Fuel Coolant Interaction) は、蒸気爆発の物理現象を理解 する上で重要なプロセスとなる。これまで、X線ラジオ グラフィによる溶融ジェットの破砕過程の撮影例はある が 5)、ジェットの多次元的な分布や界面面積に関する定 量的な情報は得られていない。そこで、本実験では液体 ジェットの液体プール侵入時における基碟的な流体力学 特性を調べるため、高速 X 線 C T装置を用いて、ジェッ 卜界面構造の可視化を行った。

\section{1 実験装置および実験条件}

実験ではジェットの液体として水、プールの液体とし てフロリナート（PF-5060、3M 社、沸点 56.7C@1tam） の非混合二成分流体の組み合わせを用いた。水ジェット は、タンクから電磁升を介して静水压でフロリナートの プール中に注入される。ジェット速度は、静水圧とジェ ットノズルを変える事によって、1.1 3.4m/s の範囲で 制御した。ノズル径としては、0.8,2.3,4.0mmの3 種類 を用いた。また、水ジェットの侵入に対する蒸気発生の 影響を調べるため、水ジェットをタンク内で加熱し、ジ エット界面でフロリナートを沸騰させた場合のジェット 形状を計測した。各流体の物性および実験条件を Table2 に示す。

\section{2 ジェットの界面形状計測}

高速 X 線 C T計測を行う前に、ジェットの様子を高速 度ビデオで撮影したものをFig. 6 に示す。ジェットの侵 入に伴い、界面の不安定性から液体塊が剥離し、浮力に よって上昇している。また、水ジェットを加熱した場合 はジェットの界面でフロリナートの沸騰が起こり、気泡

Table 2 Physical Properties and Test Conditions

\begin{tabular}{ll}
\hline Water Temp. & $22.0-91.1 \mathrm{C}$ \\
Fluorinart Temp. & $16.5-23.4 \mathrm{C}$ \\
Water/Fluorinart Density & $956 / 1680 \mathrm{~kg} / \mathrm{m} 3$ \\
Interfacial Contact Temp. & $68.1-79.0 \mathrm{C}$ \\
Nozzle Diameter & $0.8,2.3,4.0 \mathrm{~mm}$ \\
Inlet Jet Velocity & $1.1-3.4 \mathrm{~m} / \mathrm{s}$ \\
Jet/Pool Volume & $1.2-16.0 / 900.0 \times 10^{-4} \mathrm{~m}^{3}$ \\
Jet Froude Number & $32.0-1450$ \\
No Air Entrainment & \\
\hline
\end{tabular}




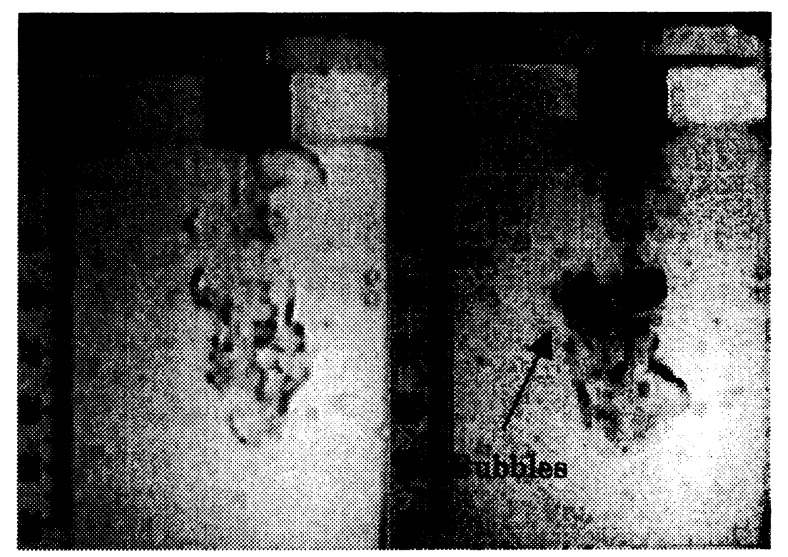

(a) Unheated Jet

(b) Heated Jet

Fig. 6 Water Jet Penetration through Fluorinart Pool

が形成されている。また、ジェットと気泡の浮力が㗢く ため、ジェットの侵入深さは加熱ジェットの方が短い。

界面の解析では、ジェット形状の全体像を把握する必 要があるため、ジェットノズルを一定速度で上昇させな がらC T撮影を行った。このときの上昇速度は $0.022 \mathrm{~m} / \mathrm{s}$ であり、ジェット速度の $2 \%$ 以下なので、ジェット形状 に対するノズルの上昇は無視できると仮定した。これに よって得られたジェットの断面積と界面長さの変化をプ ロットした図が Fig.7 である。ジェット断面積と界面長 さは、それぞれジェットノズルの断面積と内径で規格化 している。ジェットの断面積は最大でノズル断面積の約 10 倍に拡大している。ここで円形の断面積を仮定する と、この円の円周はノズル出口での輪郭長さの $10^{0.5}=3.2$ 倍となるはずである。ところが、画像処理から求めた界
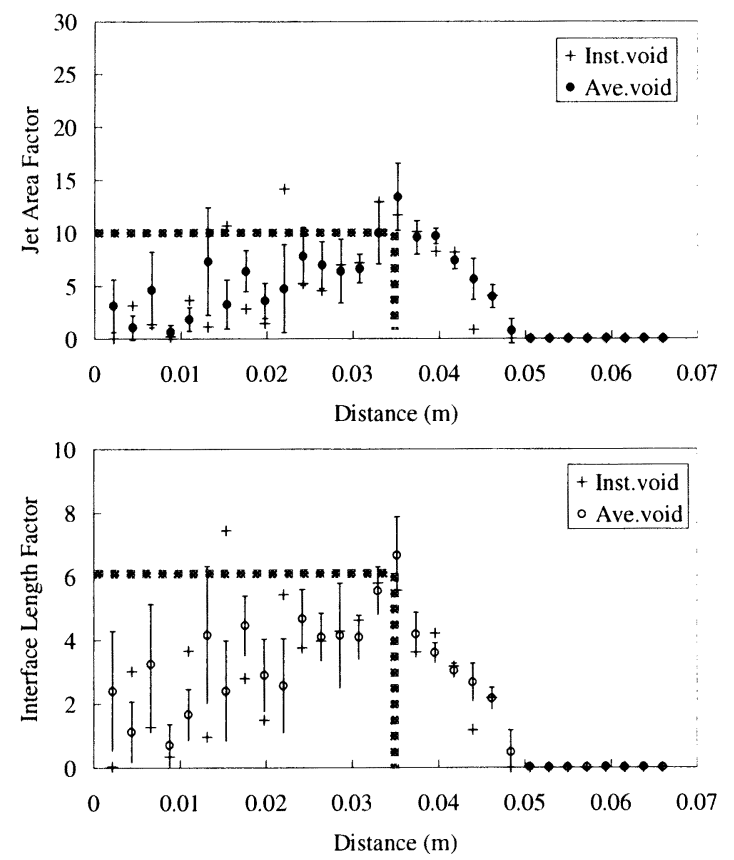

Fig. 7 Jet Cross-section Area and Interface Length normalized with Nozzle Dimensions

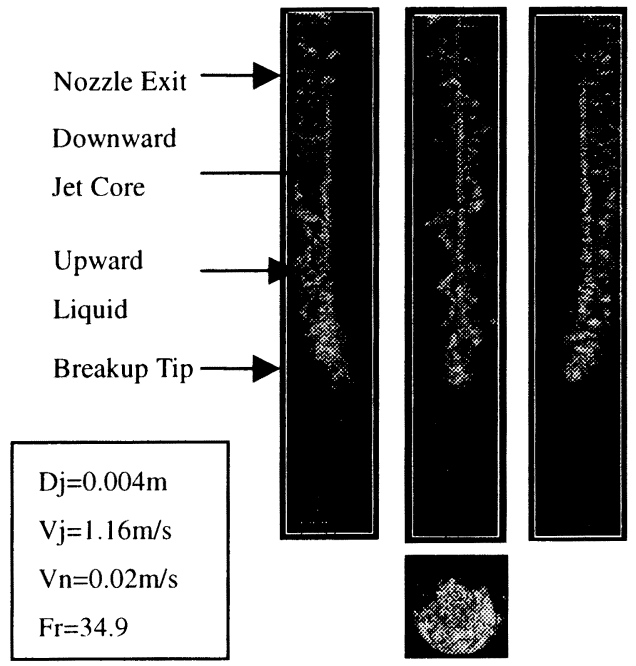

Fig. 8 3D Representation of Overall Jet Interface Structure

面長さは約 6 倍となっており、断面積から換算した界面 長さの 1.9 倍となっている。これは、ジェット界面形状 が大きく変形していることを示しており、界面面積の計 測にはX 線 C T のような多次元計測が不可欠であるこ上 を示唆している。

ノズルの上昇速度をもとに、断層像間の距離を求め、 3 次元表示したものが Fig.8 である。プール中に侵入し たジェットコアは、ブレークアップするまでほぼ垂直に 侵入し、剥離した液体がジェットコアの周囲を浮力によ って上昇している。加熱ジェットの実験では、水ジェッ 卜 $\left(956 \mathrm{~kg} / \mathrm{m}^{3}\right)$ とフロリナート蒸気 $\left(14 \mathrm{~kg} / \mathrm{m}^{3}\right)$ の密度 は共にフロリナート液体密度 $\left(1680 \mathrm{~kg} / \mathrm{m}^{3}\right)$ よりも小さ いため、これらを分離して識別することはできないので、 両方の界面が可視化されている。今後、これらを識別す る計測手法の検討を進めていく予定である。

\section{5.まとめ}

高速 X 線 C Tを気液二相流および液体ジェット実験に 適用し、界面構造を多次元的に可視化すると同時に、ボ イド率や界面積濃度を定量的に求めた。今後、データベ 一スの蓄積を図ると同時に、装置の高分解能化を進めて いく考えである。

\section{参考文献}

1) Ishi i,M. and Mishima, K. ., NUREG/CR-1873 (1980)

2）原子炬における熱流動数值解析の現状(II)、日本原子力 学会 (1987)pp. 47-54

3) RELAP5/MOD3. 2 Code Manual, Vol. 4, NUREG/CR-5535 (1995)

4）シビアアクシデントと新型軽水炉の熱流動挙動研究の現 状、日本原子力学会 (1994)pp. 27-42

5) Ciccarelli, G. and Frost,D., "Fragmentat ion mechanisms based on sigle drop steam explosion experiments using flash X-ray radiography", Nucl. Eng. Design, Vol. 146 (1994) pp. 109-132 